\title{
What Informs and Inspires the Work of Equity Minded Teachers
}

\author{
Stephanie Tuters \\ OISE/UT \& Niagara University
}

\begin{abstract}
This article explores teachers' reasons for engaging in equity work. Although multiple bodies of literature discuss teaching for equity from different perspectives, little empirical data exists about what informs or motivates people to teach for equity. This study aims to help fill that gap in existing research with the purpose of informing professional development and training for practicing teachers hoping to or attempting to engage in equity work, and for encouraging and motivating other educators in beginning to engage in equity work. Data was gathered through interviews with 15 teachers from three large school boards in Southern Ontario. Findings illustrate that participants were motivated to engage in equity work because of personal experiences with inequity, witnessing other people experience inequities, and learning about inequities in school. Three key findings stand out with regards to their utility for professional development and training: all participants spoke of critical incidents which compelled them to do equity work; emotional struggles were associated with their work, yet they remained hopeful in the possibility of change regardless of what they had experienced; finally, the nature of the equity work that participants chose to undertake was directly related to the nature of their experience with in/equity.
\end{abstract}

Keywords: Teachers, motivations, equity work, experiences of inequity, witnessing inequity, learning about inequity

Stephanie Tuters, Ph.D., is currently a Lecturer at the Ontario Institute for the Studies in Education (OISE) of the University of Toronto, and Niagara University. Her doctoral thesis, supported by Ontario Graduate Scholarships and University of Toronto Scholarships, explored how teachers understand, experience, and respond to inequities in elementary schools. Stephanie has presented research relating to leadership and teaching for social justice at both academic and practitioner conferences; this work can also be found in both academic and practitioner publications.

\section{Email: stephanie.tuters@mail.utoronto.ca}


This article describes a study exploring teachers' reasons for engaging in equity work. The study is in response to the growing diversity in the student population in Ontario, and the increasing need for teachers who are able to respond to that diversity in an equitable fashion (Brown, Wiggins, and Secord, 2009; Gerin - Lajoie, 2008; Solomon, Singer, Campbell, Allen, $\&$ Portelli, 2011). Ontario is an increasingly diverse province. For example, Ontario receives around $40 \%$ of all immigrants to Canada on a yearly basis with a large portion of those immigrants settling in the Greater Toronto Area (GTA) (Ontario Ministry of Finance, 2011a). It is projected that by 2036 net migration will account for $68 \%$ of the population growth in the province (Ontario Ministry of Finance, 2011b). Regrettably, although there are many positives associated with diversity, and Ontario as a province celebrates diversity, differences in academic achievement exist which are related to characteristics of diversity such as socioeconomic status, and ethnicity. For example, "recent estimates from the Toronto District School Board (TDSB) indicate that as many as 40 per cent of Caribbean-born students and 32 per cent of those born in Eastern Africa, and 28 per cent of students from Western Africa dropped out of high school" (Brown, 2006 as cited in Sweet, Anisef, Brown, Walters \& Phythian, 2010, p. 10). Further, the Thames Valley District School Board (TVDSB) in London Ontario had a five-year high school graduation rate of $77 \%$ in 2014 while the Halton District School Board (HDSB) had a five-year graduation rate of $88 \%$ (Ontario Ministry of Education, 2015). The director of the TVDSB was quick to point out that their students experience great challenges in their academic pursuits, particularly relating to family income. The students in the TVDSB experience higher levels of poverty than students at other school boards such as the HDSB (Dubinski, 2015).

School boards such as the Toronto District School Board have acknowledged that achievement gaps exist which are directly related to race which they state they "must continue to work on" (Malloy, 2016). As a result, they have set up programming such as the Inner City Schools program, and the Afrocentric School, to help eliminate such achievement gaps, along with a comprehensive Inclusive and Special Education Plan to "ensure that every student, every day, in every school is welcomed and included within the most enabling learning environment" (Toronto District School Board, 2014). These policies and programs relate to the Provincial mandate which is focused on increasing equity and inclusion in Ontario public schools, and is described in the Ontario Ministry of Education Equity and Inclusive Education Strategy (2008). The ministry of Kathleen Wynne acknowledged in the Equity and Inclusive Education Strategy (2008), that barriers to inclusion exist in Ontario schools, and that they need to be addressed and removed (p. 2). Teachers doing equity work is one way in which these barriers to inclusion can be overcome.

Few scholars have investigated the understandings and beliefs held by teachers who choose to engage in this work. Those who have researched this topic note that the lives of equity minded educators informs their practice, yet their voices of critical educators are unfortunately uncommon in existing literature and need to be uncovered (Mogadime, 2011, 2012; Mogadime \& Smith, 2007). Researchers also note that many teachers unfortunately hold deficit conceptions of students, even those educators who claim to be engaging in equity and social justice work, and that this issue should be addressed in training and education (Sleeter et al., 2004); and that teacher candidates are often resistant to overcoming these deficit conceptions and adopting an equity lens to inform their practice (Brown, Wiggins, \& Secord, 2009). Data from this study can be used to inform professional development, education, and further research, by uncovering what encourages people to teach for equity. In particular, data can be used to support existing equity minded educators in developing their craft in the form of

Brock Education Journal, 26(2), 2017 
professional development and training, and for encouraging others to engage in work that contributes to the creation of more equitable and inclusive schools.

\section{What is Equity/Inequity?}

Equity is popularly discussed in education, yet it is a complicated term with multiple meanings. For some, equity means that everyone should receive the same things (Jencks, 1988, p. 519). For others, equity means more should be given to those in need (Jencks, 1988). For others still, equity includes calculations of merit based on fair or meritocratic competition (Jencks, 1988). Determining who should get what and how is not an easy task and it is highly dependent on context and the distribution of political power (Stone, 2012). Those with more voice and political power will have a greater influence over the distribution of all other assets. Broadly speaking, for this article the term equity is used to describe processes where individuals are working to achieve fair and equal opportunities for all students, based on their individual needs, it "does not necessarily entail equal treatment" (Solomon et al., 2011, p. 15). In this case, the work that equity minded educators are doing will be specifically targeted towards helping students to overcome barriers to achievement such as discrimination and oppression based group membership and identity characteristics, and other barriers associated with things such as socio economic status and access to high quality educational programming and opportunities (Banks \& Banks, 1995; Ryan 2012).

\section{What is Equity Work?}

Equity work can take many forms, including but not limited to: differentiating instruction and materials based on student needs (Delpit, 1995); encouraging participation in schooling from all stakeholders (parents, community organizations etc.) about what education should be like (Athanases \& De Oliveira, 2008; Ladson-Billings, 1995; Smith, Wohlstetter, Kuzin \& De Pedro, 2011); ensuring students can see themselves, their backgrounds, and their beliefs reflected in their education (Dei et al., 2003; Ladson-Billings, 1995; Rios \& Montecinos, 1999); ensuring all students have the resources and opportunities to achieve success, broadly defined as respecting the multiple and differing beliefs and values of students and community members (Banks \& Banks, 1995; Ladson-Billings, 1995; Nieto, 2004); helping students to develop agency to change their situations (Picower, 2007); and providing an academically rigorous environment that is supportive of the development of critical thinking (Freire, 2000; Jay, 2003; Nieto, 2004). The question that this study explores is why educators engage in these types of activities, and what informs their understanding, beliefs, and actions regarding equity.

\section{Why do Equity Minded Teachers do Equity Work?}

It has long been said that past experiences and beliefs inform teachers' actions (Irvine, 2003; Villegas, 2007). It has also been stated that it is problematic that the majority of teachers in North America are white when many of their students are of diverse backgrounds (Brown, Wiggins, \& Secord, 2009; Ryan, Pollock, \& Atonelli, 2009), as white teachers have often not experienced inequity and may be less capable of understanding the experiences of their students, particularly in comparison to their colleagues who have experienced discrimination and oppression (Howard, 1999; Sleeter, Torres, \& Laughlin, 2004). In research articles focusing on equity, comments are made about how people have different kinds of 
understandings of things like equity and diversity (Howard, 1999; Sleeter et al., 2004), yet very few scholars have investigated the understandings and beliefs held by teachers before attempting to change them (see for example Sleeter et al., 2004). Research regarding teachers' understandings and beliefs regarding equity and inclusion, in particular - why they choose to engage inequity work, is scant. Mogadime (2011) investigated the experiences of two critical educators, and how their identity informs their attempts to engage in antiracist and critical multicultural work in their schools, and found that the teachers' previous experiences and knowledge were highly informative for their equity practices. This study is therefore informed by the work of Mogadime (2011) as well as research on this topic in relation to the experiences of educational leaders as it is more developed (Griffiths, 2010; Singh, 2010; Theoharis, 2007).

Educational leaders who engage in equity work are described as being able to recognize that society and societal institutions marginalize certain groups and work to decrease inequities through their work (Theoharis, 2007). They are portrayed as deriving their motivation to do equity work from: previous experiences with marginalization or oppression, what they learned from these experiences, and what they would like to see changed as a result (Griffiths, 2010; Singh, 2010; Theoharis, 2007). Church or religious upbringing is often integral to the development of this responsibility to help others and community (Singh, 2010; Theoharis, 2007). Administrators often cite family and other close relationships, such as with mentors, as a source of influence; they refer to their parents as having shown them how education can be the route to a better life or a better world and helping to motivate them to contribute to equitable changes (Griffiths, 2010; Singh, 2010; Theoharis, 2007). Finally, geography or context is often influential. This could include living in an area where marginalization and oppression are commonly experienced, or in a particular time period - having grown up in an era such as the 1960s or 1970s when social justice and activism were common (Griffiths, 2010; Singh, 2010; Theoharis, 2007).

\section{The Cost and Complications Associated with Equity Work}

There are costs and complications associated with engaging in equity work, it is no easy task. Those who choose to engage in equity work often experience conflict with stakeholders such as colleagues, superiors, and parents (Ryan, 2012). Engaging in equity work can also associated with a lack of promotion and retention, isolation, and emotional distress related to engaging in processes such as retrospective meaning making to change and challenge ones thinking (Bell, Love, Washington, \& Weinstein, 2007; Boler \& Zembylas, 2003; Picower, 2011). Even those who believe strongly in the value of equity work and are committed to creating positive change are often ill equipped to deal with the challenges of this work (Tatar, \& Horenczyk, 2003) and can be subsequently pressured to make an early exit from teaching (Picower, 2007). Those who work with aspiring and practicing educators, attempting to encourage and support them in engaging in equity work experience challenges such as deficit thinking (Lipsitz, 2006; McIntosh, 1990) and resistance to change (Brown, Wiggins, Secord, 2009; Merryfield, 2000; Milner, 2010; Picower, 2011). One way of helping to mediate the effects of this environment, to contribute to the sustainment of existing equity work, and to encourage the development of new equity workers, is to learn more about the reasons current educators have for teaching for equity, and what they think attributed to their development as equity minded individuals. This data can be used to inform professional development, education, and further research, with the goal of supporting existing equity minded educators in developing their craft, and encouraging others to engage in work that contributes to the

Brock Education Journal, 26(2), 2017 
creation of more equitable and inclusive schools.

\section{Theoretical Framework}

This study is informed by theories of equity and social justice mentioned above and is guided by a critical lens, with the goal of problematizing things such as disparate achievement levels in education to help bring about positive changes and decrease inequities. Aspects of critical theory which inform this study include: the belief that everything is political, including lack of action; what teachers and administrators choose to do, and choose not to do indicate a political perspective or inclination; the belief that people (students) are unique fountains of knowledge; students are not empty vessels to be filled with information (Freire, 2000; 2001). Along with this comes the importance of incorporating the individual knowledge and experiences of teachers and students into education, and a belief in positive change or as Kincheloe (2004) and Freire (2000; 2001) might call it - radical love which leads to action and therefore positive change. A critical approach to educational research: "seeks to emancipate the disempowered, to redress inequality and to promote individual freedoms within a democratic society" (Cohen, Manion \& Morrison, 2007, p. 26). A fundamental goal of this study is to assist in making education more equitable and inclusive through examining and uncovering why equity-minded educators choose to engage in equity work.

\section{Methods}

The central question guiding the data analysis was - what informed, influenced, or motivated educators to attempt to decrease inequities through their actions as teachers and how did these experiences influence their practice? Data was collected using qualitative research methods (Merriam, 1998), as they are uniquely equipped to explore topics of which little is known. Designed to gather baseline information regarding teacher motivations, this study is primarily descriptive and exploratory. One on one, face to face interviews with teachers were used to gather data. Interviews were chosen as the method of data collection for their capacity to gather rich in depth information about a previously understudied topic. They also allow for flexibility in questioning (Merriam, 1998).

The style of the interview was relatively informal, much like a "conversation with a purpose" (Mason, 2006, p. 62), where the purpose was to get a narrative like account of teachers' viewpoints. Interviews started with a general discussion to familiarize the participants with the purpose of the study and help relax them before any of the questions were asked. The interview was more structured at the beginning, asking the participants to answer simple questions about age, gender, years of teaching experience, and current occupation, which provide a context for the discussion. As the interview progressed questions were less specific, providing greater opportunities for the participant to share narrative like accounts of experiences and thoughts on the topics.

The goal was to have the interview be co-constructed by the interviewer and interviewee, rather than a static process with a power imbalance which favours the interviewer (Rapley, 2001). Interviews varied in length, from half an hour to three hours, with the average length of the interviews being one and a half hours. For the most part, the length of the interviews related to the amount of years of experience the educators had been engaging in equity work. Some of the participants had more to say than others as they had more experiences engaging in equity work. At the end of the interview each of the participants was given the option of reviewing

Brock Education Journal, 26(2), 2017 
the transcripts and making and changes or additions.

Elementary school teachers from Ontario who self-identified as actively engaging in equity work in their schools were invited to participate in the study through a network of educators located at the Ontario Institute for Studies in Education entitled the Centre for Leadership and Diversity (CLD). A recruitment email was sent out to members of the CLD, members were asked to consider participating as well as forwarding on the email to their colleagues that might be interested in participating. Participants included those who held formal leadership roles within their schools, such as the leaders of the equity clubs or teams, as well as those who engaged in equity work in their every-day classroom work yet perhaps did not hold a formal title or belong to an equity group.

The participant group was comprised of teachers from three large school boards in Southern Ontario. The three school boards represent large diverse urban areas. An effort was also made to include a diverse participant group. Eight of the participants were female, seven were male. Many of the participants self-identified as being part of a marginalized group: one of the participants was a lesbian, one was gay, one was transgendered, two were black, two were immigrants, and two of them mentioned being second generation Canadian and having witnessed their parents being marginalized for not being considered to be Canadian. Participants were given pseudonyms that were similar in style to their original names but provided them with anonymity. The pseudonyms used were: Alana, Inta, Joana, Melony, Kurtis, Remi, Sarah, Kent, Sidney, Matt, Lesley, Mitch, Kristen, Bud, and Kelsey. An effort was made to exclude any information from the results that would allow the participants to be identified by a reader as much of the information that was shared by participants was of a deeply personal and sensitive nature.

Interviews were recorded using a voice recorder and transcribed at a later date. Notes were taken in a journal during and after the interviews and during the data analysis process. Interviews were transcribed into a word document. These word files were read to uncover initial themes that were informed by the literature review regarding educational leaders' reasons for engaging in equity work, and then uploaded into Nvivo and coded using these themes while still remaining open to new themes that emerged through repeated re-reading of the transcripts, using grounded theory (Creswell, 2015). The main themes that were uncovered using grounded theory included: having personally experienced inequity, having witnessed other people experiencing inequity, having learned about inequity through their education.

\section{Findings: Participants Reasons for Engaging in Equity Work}

Participants identified three main sources of motivation that included personally experiencing inequities, witnessing others experience marginalization, and being exposed to education about inequities and diversity either through their upbringing or their formal schooling.

\section{Personally Experiencing Inequities}

The most common reason participants gave for why they do equity work was having personally experienced inequities. Six participants described their personal experiences with inequities, and how they were influenced by them. These participants spoke of experiences they had in school settings, times when they had felt powerless, without a voice, and treated like an outsider or other and lacking agency. Inta described her experience as an immigrant

Brock Education Journal, 26(2), 2017 
and how it instilled in her a passion to teach for equity. She and her family immigrated to Canada from Eastern Europe when she was a young girl. She had many wonderful memories of her childhood home that were not reflected in the education she received in Canada. Misinformation and misinterpretation led to her home country and her people being vilified during the class lessons regarding World War 1. Inta said:

When I was in high school there was a textbook written about the war in XXXX, which is the country that I immigrated from. It talked about how the XXXX people were these evil people that started the First World War, and that wasn't my reality. And that was my first experience with that, it was a jarring experience and I remember shutting down in that class whenever conversation around that happened and it wasn't an environment where I felt comfortable to challenge that and say to my teacher - I don't agree with that.

Inta's educational experiences in Canada began with her being marginalized and misunderstood by her peers because of the way her teachers taught them about world events involving her home country. She felt ashamed and hurt about the way her home country was portrayed and like she wanted to change the system so other children would not have the same experiences as her.

Inta described how it was not until she became a teacher, was given a position of power, and accepted by "the system", that she began to feel accepted and Canadian. With this acceptance came an even greater desire to change things for the better. Inta was encouraged by her experiences to try to engage in equity work in her school. She identified two goals of her equity work, to help her students develop critical literacy skills and to help create an educated electorate, with the overarching goal of contributing to the creation of a more equitable society. She stated her belief that doing equity work is a "moral imperative". She concentrates her efforts around helping her students to be smart consumers of knowledge and learning the tools they need to think understand and think critically about the world, their place in it, and to make their own contribution to the creation of a more equitable world.

\section{Witnessing Inequities}

For five of the participants it was witnessing other people experience inequities or seeing their families and friends participating in inequitable behaviours that influenced and informed their equity work. Participant Melony's experiences travelling and living abroad as a child, because of her fathers' job, had initiated her development as an activist and critical thinker. A few events really stood out to her as critical moments. One was a trip to a local market with her parents:

For me, the image in my mind is always this little girl that I saw in Thailand, she had had her feet slashed for begging. We were at this market, so my parents were looking at fake alligator shirts, the Lacoste shirts, and they were haggling over how much for a dozen. And this girl was sitting right there and she was about the same age as I was. And because she was sitting there she wasn't learning how to develop a water filtration system that would help her own village. Or she wasn't able to get excited about painting or whatever it was that would be her thing to do. And all around her people were not seeing her, they were walking around and engaging in the superficial commerce.

One of the things that stood out to her the most about this situation was that her parents seemed oblivious to what was happening. When Melony looked around in astonishment, assuming

Brock Education Journal, 26(2), 2017 
someone would assist this girl, she was struck by that fact that this inequitable situation was somehow normalized and acceptable to those around her. She felt her parents and the other shoppers at the market were more concerned with their purchases than they were about the feelings and situations of others. Melony described her parents as nice people, of whom she was quite fond. However, she also described them as unaware and possibly disinterested in the fact that inequities existed and the fact that they might be contributing to the inequitable situations of others through their actions and inactions. Coming to this realizing was a difficult emotional process.

These feelings and questions resulting from Melony's experiences inspired her work as an educator and her beliefs about what people could and should learn. Melony had learned through her travels that people who enjoyed powers and privileges such as herself could choose to acknowledge the reality of their existence and the roles they played in contributing to inequitable situations, and they could become aware and interested in making positive changes. As a result of her experiences Melony had decided to help her students and colleagues develop critical consciousness, to incorporate multiple and global perspectives in her classroom, and to be transparent and educative of the different power relationships existing in schools. She attempted to get students to question where they fit in the formal and informal hierarchies of society and how they could express agency to create changes. Melony was also influenced to do this work in an affluent school as a result of her experiences. She felt it was very important to try to reach students who currently occupied positions of relative power, and would likely occupy positions of even more power in their adulthood.

\section{Learning About Inequity Through Education}

The third main reason participants gave for doing equity work was their education. Participants described how they had learned about equity and inequity, and felt compelled to teach for equity, as a result of formal or informal learning. Participant Matt described his motivation for engaging in equity work as beginning in university. He said:

In my masters work I have really had to think about it actually think about how I approach it as a teacher. Because when I think about my own identities and the bias that I bring and the various things that I carry with me and the various things that I portray to others just because of who I am, it carries different weights, different stigmas, and I need to be aware of that to be able to access and reach every single student on a human level.

He credited his formal schooling as helping him develop an awareness and desire to be more equitable. Matt described himself as a middle class White man. Although he had grown up in a very diverse area of a large city, he did not feel like he had really been "forced" to challenge himself and think about who he was in relation to others until he went to university. As a result of what he learned in university, he developed a desire to know more and to make changes. He began to understand that he had a particular identity that shaped how he perceived things and how other people perceived him. His identity also influenced the kinds of access and experiences he had. He therefore desired to learn more about people in general, what they had experienced, what personal biases people might have that could influence how they viewed one another, and the different ways he could get involved in equity work. He used this awakening that happened through his education to help inform his everyday classroom teaching, and in his interactions with his colleagues. He worked hard to be equitable as an educator and encourage his colleagues to do so as well by discussing what he was doing in his

Brock Education Journal, 26(2), 2017 
class and questioning his colleagues about how they could attempt to do similar things in their classes. Though, he highlighted that this was challenging, particularly when working with colleagues who had personally not experienced discrimination.

\section{Discussion}

Whether participants had personally experienced inequities or learned about them in school, commonalities emerged with regards to the kinds of things participants learned as a result of their experience, and how they influenced their equity practice. Three key findings stand out with regards to their utility for professional development and training in terms of assisting those currently engaging in equity work, and those providing professional development and training to aspiring and practicing equity minded educators. The findings are particularly useful in terms of their value for helping equity minded educators overcome challenges associated with engaging in equity work. All participants spoke of critical incidents which compelled them to do equity work. Emotional struggles were associated with their work, yet they remained hopeful in the possibility of change regardless of what they had experienced. Finally, the nature of the equity work that participants chose to undertake was directly related to the nature of their experience with in/equity.

All participants spoke vividly of critical incidents which informed their equity work. For some participants, the incidents took place in university programs, whereas for others they were personal experiences such as when Melony traveled abroad with her family. Studies involving prospective teachers that investigate the effect of service learning on their beliefs regarding things such as equity and diversity demonstrate similar findings with regards to the power of critical incidents. For example, Baldwin, Buchanan, and Rudisil (2007) found that for many of their participants, their service learning experiences were the first time they had experienced student diversity and their experiences were found to be successful at helping them to see things from alternate perspectives. Mogadime (2012) found that "teachers' growing awareness of social inequalities through critical incidents beginning in childhood, adolescence and adulthood" (p. 199). Findings such as these suggest that programs designed with the purpose of enticing educators to become equity minded in their practice could be successful if they incorporated either in service components or educational components that encourage participants to develop the ability to see things from multiple perspectives as well as the impetus for equity work.

Things such as critical reflection could be used with educators working in diverse communities to help unpack their experiences, and the experiences of their students and surrounding communities and how educators could change their thinking and practice to become more equitable. Merryfield (2000) uses the term "retrospective meaning making" to describe a process through which she asked teacher educators reflect on their past experiences and make meaning out of them for their current practice. Milner (2007) endorses the power of reflecting on past experiences for expanding one's knowledge and understanding of how and why to teach for equity, and for improving future teaching practice. Milner also argues that this reflection can be particularly useful for people who might be resistant to this kind of work such as those who occupy positions of power and privilege and have a hard time seeing things from other people's perspectives.

The second key finding is that participants spoke about experiencing challenges associated with their equity work which they described as taking a personal toll on them. Being resistant to engaging in equity work or thinking critically about identity and power are commonly

Brock Education Journal, 26(2), 2017 
researched phenomena (see for example Lipsitz, 2006; McIntosh, 1990). Much less frequently discussed are the emotional challenges experienced by those who willingly engage in equity work. Although the research that does exist suggests that those engaged in equity work are more likely to experience burn-out and leave the profession early (Tatar, \& Horenczyk, 2003; Picower, 2007). The role of emotions in engaging in equity work is scarcely discussed, and when it is, it is largely in relation to the emotional discomfort involved in shifting ones' worldviews (Bell, Love, Washington, \& Weinstein, 2007; Boler \& Zembylas, 2003; Picower, 2011). Ryan and Author (in press) explore the emotional work of educational leaders in Ontario who choose to lead for social justice. They found that there are serious emotional burdens associated with leading for social justice, and that for some, the bulk of their social justice work involves managing (or attempting to manage) the emotions of others (Ryan \& Author, in press). Left unaddressed is the emotional cost associated with engaging in equity work, particularly with regards to the emotional turmoil teachers experience resulting from their students and colleagues resisting work about which teachers feel so passionately. This study lends support to the notion of creating mentorship and support groups for those who choose to engage in equity work, and for those who might be convinced of its value. The participants in this study who mentioned feeling challenged in their attempts to do this work, also often mentioned the support they received from like minded colleagues, and how much they valued this camaraderie in their attempts to do equity work. Communities could therefore be a powerful tool for sustaining equity work in education (Katsarou, Picower and Stovall, 2010; Picower, 2011).

Participants also expressed their belief in positive change regardless of how awful the things were that they had experienced, witnessed, and learned about. Participants believed that they could and should play a role in achieving greater equity and inclusion through their work as educators. This belief in finding and achieving "good" in society is often discussed in equity related literature. Merryfield's (2000) participants espoused similar beliefs about being able to find the good in bad people and situations and enhancing this good through their work as educators. Freire describes this feeling as "radical love". In their work on social justice leadership, Miller, Brown, and Hopson, (2011) suggest that beliefs in radical love and positive change, are more than just niceties, they could represent a complete reframing of educational leadership. With regards to supporting and sustaining teachers' equity work, conceptualizing equity work as coming from a place of love and positivity could be helpful for supporting those currently engaged in equity work and encouraging new teachers to engage in equity work.

Finally, the nature of the equity work which participants chose to undertake in their teaching careers was directly related to the descriptions participants gave of their experiences with in/equity. For example, Inta described how she had experienced marginalization and discrimination related to immigrating to Canada from a country which was in conflict and negatively perceived by society as a result. These experiences led her to develop a critical perspective, especially regarding sources of authority that are often taken for granted such as the government. Later in her interview she went on to describe how one of her fundamental goals as an equitable educator is to teach her children to be critical thinkers. She wanted to teach them to constantly question the world around them and their role. Findings such as this are consistent with the research on this topic by Mogadime (2011), and suggests that targeted placements or educational experiences could be used that relate directly to the experiences of in/equity of the students with which prospective teachers will be working, or for teachers who are currently practicing. 


\section{Conclusion}

The goal of this study was to uncover the ways in which past experiences and learning influenced the development of the teachers involved in this study, what made them decide to become people who teach for equity, and how they incorporate this knowledge into their practice, with the further purpose of informing professional development and training of aspiring and practicing equity minded educators. Participants in this study identified personal experiences with inequities, having witnessed others experiencing inequities, and having learned about inequities in school as encouraging and influencing them to teach for equity. Findings such as this help fill the gap in the small but growing body of research regarding what influences and informs the work of those teaching for equity. Findings also provide baseline information for more in depth investigations into why teachers choose to engage in equity work, for the purpose of supporting those who choose to engage in equity work and encouraging other educators to follow suit. 


\section{References}

Athanases, S. Z., \& De Oliveira, L. C. (2008). Advocacy for equity in classrooms and beyond: New teachers' challenges and responses. Teachers College Record, 110(1), 64-104.

Baldwin, S. C., Buchanan, A. M., \& Rudisill, M. E. (2007). What teacher candidates learned about diversity, social justice, and themselves from service-learning experiences. Journal of Teacher Education, 58(4), 315-327.

Banks, J. A. (2008). Diversity, group identity, and citizenship education in a global age. Educational Researcher, 37(3), 129-139.

Banks, J. A., \& Banks, C. A. M. (1995). Equity pedagogy: An essential component of multicultural education. Theory into Practice, 34(3), 152-168.

Bell, L. A., Love, B., Washington, S., \& Weinstein, G. (2007). Knowing ourselves as social justice educators. In M. Adams, L. A. Bell, \& P. Griffin (Eds.), Teaching for diversity and social justice (2nd ed., pp. 381-393). New York, NY: Routledge. (Original work published 1997)

Boler, M., \& Zembylas, M. (2003). Discomforting truths: The emotional terrain of understanding differences. In P. Tryfonas, (Ed.), Pedagogies of difference: Rethinking education for social justice. New York: Routledge. 110-136.

Brown, N., Wiggins, R., \& Secord, D. (2009). This must be a suburban classroom!: Using photographs to investigate teacher candidates developing professional identities. Brock Education Journal, 18(2), 49-65.

Cohen L., Manion L., Morrison K. (2007). Research methods in Education. New York, NY: Routledge.

Cooper, K., \& White, R. E. (2004). Burning issues: Foundations of education. Oxford, UK: ScarecrowEducation.

Creswell, J. W. (2015). Educational Research: Planning, Conducting, and Evaluating Quantitative and Qualitative Research, Enhanced Pearson eText with Loose-Leaf Version--Access Card Package. Pearson Education, Inc.

Dei, G. J. S., James, I. M., Karumanchery, L. L., James-Wilson, S., \& Zine, J. (2003). Removing the margins: The challenges and possibilities of inclusive schooling. Toronto, Ontario, Canada: Canadian Scholars' Press.

Delpit, L. (1995). What should teachers do? ebonics and culturally responsive instruction. In T. Perry, \& L. Delpit (Eds.), The real ebonics debate (pp. 17-26). Boston, MA: Beacon.

Dubinski, K. (2015, April, 20). Big discrepancies in graduation rates at Ontario school boards. The Toronto Sun. Retrieved from http://www.torontosun.com/2015/04/20/bigdiscrepancies-in-graduation-rates-at-ontario-school-boards

Flores, M. A., \& Day, C. (2006). Contexts which shape and reshape new teachers' identities: a multi- perspective study. Teaching and Teacher Education, 22, 219 -232.

Freire, P. (2001). Pedagogy of Freedom: Ethics, democracy, and civic courage. New York: Rowman \& Littlefield Publishers Inc.

Freire, P. (2000). Pedagogy of the oppressed. New York, NY: The Continuum International Publishing Group.

Gerin-Lajoie, D. (Ed.). (2008). Educators' discourses on student diversity in Canada: Context, Policy, and Practice. Toronto, Ontario, Canada: Canadian Scholars Press.

Griffiths, D. (2010). Urban elementary principals' approaches to inclusion. Unpublished

Brock Education Journal, 26(2), 2017 
doctoral thesis, University of Toronto.

Howard, G. R. (1999). We can't teach what we don't know: White teachers, multiracial schools. New York, New York: Teachers College Press.

Irvine, J. J. (2003). Educating teachers for diversity: Seeing with a cultural eye. New York, New York: Teachers College Press.

Jay, M. (2003). Critical race theory, multicultural education, and the hidden curriculum of hegemony. Multicultural Perspectives, 5(4), 3-9.

Jencks, C. (1998). Whom must we treat equally for educational opportunity to be equal? Ethics, 98 (3), 518-533.

Katsarou, E., Picower, B., \& Stovall, D. (2010). Acts of solidarity: Developing urban social justice educators in the struggle for quality public education. Teacher Education Quarterly, 137-153.

Kissen, R. M. (2002). Getting ready for Benjamin: Preparing teachers for sexual diversity in the classroom. Lanham, MD: Rowman \& Littlefield.

Kincheloe, J. L. (2004). Critical pedagogy. New York, NY: Peter Lang.

Kumashiro, K. (2002). Against repetition: addressing resistance to anti-oppressive change in the practices of learning, teaching, supervising and researching. Harvard Educational Review, 72(1), 67-93.

Ladson-Billings, G. (1995). But that's just good teaching! The case for culturally relevant pedagogy. Theory into Practice, 34(3), 159-165.

Ladson-Billings, G. (2006). From the achievement gap to the education debt: understanding achievement in U.S. schools. Educational Researcher, 35(7), 3-12.

Lipsitz, G. (2006). The possessive investment in whiteness: How white people profit from identity politics. Philadelphia, PA: Temple University Press.

Malloy, J. (2016, July 29). TDSB's plan to tackle racial disparity. The Star. Retrieved from https://www.thestar.com/opinion/commentary/2016/07/29/tdsbs-plan-to-tackle-racialdisparity.html

Mason, J. (2006) (2 $2^{\text {nd }}$ ed.). Qualitative researching. Thousand Oaks, CA: SAGE.

McIntosh, P. (1990). White privilege: Unpacking the invisible knapsack. Independent School, Winter, 31- 36.

McGee Banks, C. A., \& Banks, J. A. (1995). Equity pedagogy: An essential component of multicultural education. Theory into Practice, 34(3), 152-158.

Merriam, S. B. (1998). Qualitative research and case study applications in education: Revised and expanded from case study research in education. San Fransico, CA: Jossey Bass.

Merryfield, M. M. (2000). Why aren't teachers being prepared to teach for diversity, equity, and global connectedness? A study of lived experiences in the making of multicultural and global educators. Teaching and teacher Education, 16, 429-443.

Miller, P. M., Brown, T., \& Hopson, R. (2011). Centering love, hope, and trust in the community transformative urban leadership informed by Paulo Freire. Urban Education, 46(5), 1078-1099.

Milner, H. (2005). Developing a multicultural curriculum in a predominantly white teaching context: Lessons from an African American teacher in a suburban English classroom. Curriculum Inquiry, 35(4), 391-427.

Milner, H. (2007). Race, narrative inquiry, and self-study in curriculum and teacher education. Education and Urban Society, 39(4), 584-609.

Milner, H. (2010). What does teacher education have to do with teaching? Implications for

Brock Education Journal, 26(2), 2017 
diversity studies. Journal of Teacher Education, 61(1-2), 118-131.

Mitchell, L. A. (2009). Becoming culturally responsive teachers in today's diverse classroom. Paper Presented at the 2009 American Educational Research Association Annual Meeting. San Diego, CA. pp. 1-50.

Mogadime, D. (2011). An Ethnography of two teachers' antiracist and critical multicultural Practices. Brock Education Journal, 21(1).

Mogadime, D. (2012) Using interdisciplinary feminist theory to arrive at an understanding of critical educators who put human rights at the center of school curriculum, In Cornelia Roux (Ed.), Safe Spaces: Human Rights Education in Diverse Contexts (193-206). Rotterdam, the Netherlands: Sense Publishers.

Mogadime, D., \& Smith, S. R. (2007). Including Muslim Teachers' Sensibilities into Wider National and International Discussions About Culturally Responsive Pedagogy. International Journal of Diversity in Organisations, Communities \& Nations, 7(4).

Nieto, S. (2004). Affirming diversity: The sociopolitical context of multicultural education (4th ed.). New York, NY: Allyn \& Bacon.

Ololube, N. P. (2006). Teachers job satisfaction and motivation for school effectiveness: An assessment. Retrieved from http://eric.ed.gov.myaccess.library.utoronto.ca/?id=ED496539

Ontario Ministry of Education. (2008). Realizing the promise of diversity: Ontario's equity and inclusive education policy. Toronto, ON: Queens Printer for Ontario.

Ontario Ministry of Education. (2015). 2014 graduation rates across the province. Retrieved from http://news.ontario.ca/edu/en/2015/04/2014-graduation-rates-across-the- province.html

Ontario Ministry of Finance. (2011a). Ontario Demographic Quarterly. Retrieved October 1 from http://www.fin.gov.on.ca/en/economy/demographics/quarterly/dhiq1.pdf

Ontario Ministry of Finance. (2011b). Ontario population projections update. Queens Printer.

Picower, B. (2007). Supporting new educators to teach for social justice: The critical inquiry project model. Penn GSE Perspectives on Urban Education, 5(1), 1-22.

Picower, B. (2011). Resisting compliance: Learning to teach for social justice in a neoliberal context. Teachers College Record, 113(5), 1105-1134.

Rapley, T. (2001). The art(fulness) of open-ended interviewing: Some considerations on analysing interviews. Qualitative Research, 1(3), 303-323.

Ríos, F., \& Montecinos, C. (1999). Advocating social justice and cultural affirmation: Ethnically diverse preservice teachers' perspectives on multicultural education. Equity \& Excellence in Education, 32(3), 66-76.

Ryan, J. (2006). Inclusive leadership. San Francisco, CA: Jossey Bass.

Ryan, J. (2012). Struggling for inclusion: Educational leadership in a neo-Liberal world. Charlotte, NC: Information Age Publishing.

Ryan, J., Pollock, K., \& Antonelli, F. (2009). Teacher diversity in Canada: Leaky pipelines, bottlenecks, and glass ceilings. Canadian Journal of Education, 32(3), 591-617.

Ryan, J \& Author, S. (In Press). Leadership and motions: Promoting social justice. In S. Clarke and T. O’Donoghue (Eds.), Educational Leadership in Diverse Contexts. London, UK: Routledge.

Shanahan, N. (2006). Safe at school: Gay and lesbian issues in the classroom. Our Schools, our Selves, 30-35.

Simpson, A. W., \& Erickson, M. T. (1983). Teachers' verbal and nonverbal communication as patterns as a function of teacher race, student gender, and student race. American Educational Research Journal, 20(2), 183-198.

Singh, H. (2010). Leadership for social justice: From elusive conceptions to arrested

Brock Education Journal, 26(2), 2017 
developments. Unpublished doctoral thesis, University of Toronto.

Sleeter, C. (2008a). Equity, democracy, and neoliberal assaults on teacher education. Teaching and Teacher Education, 24(8), 1947-1957.

Sleeter, C. E. (2008b). Preparing White teachers for diverse students. In M., Cochran-Smith, S., Feiman-Nemser, D. J., McIntyre, \& K. E., Demers (Eds. $3^{\text {rd }}$ ed.). Handbook of research on teacher education: Enduring questions in changing contexts (559-582). New York, NY: Routledge.

Sleeter, C., Torres, M. N., \& Laughlin, P. (2004). Scaffolding conscientization through inquiry in teacher education. Teacher Education Quarterly, 81-96.

Smith, J., Wohlstetter, P., Kuzin, C. A., \& De Pedro, K. (2011). Parent involvement in urban charter schools: New strategies for increasing participation. The School Community Journal, 21(1), 71-94.

Solomon, R. P., Singer, J., Campbell, A., Allen, A., \& Portelli, J. (2011). Brave new teachers: Doing social justice work in Neo-Liberal times. Toronto, ON: Canadian Scholars' Press.

Statistics Canada. (2009). Aboriginal identity population, by province and territory (2006 Census). Retrieved from http://www.statcan.gc.ca/tables-tableaux/sumsom/101/cst01/demo60a-eng.htm

Stone, D. (2012). Policy paradox: The art of political decision making. ( $3^{\text {rd }} \mathrm{ed}$.) New York, NY: Norton and Company.

Sweet, R., Anisef, P., Brown, R., Walters, D., \& Phythian, K. (2010). Post-high school pathways of immigrant youth. Toronto, ON: Higher Education Quality Council of Ontario.

Tatar, M., \& Horenczyk, G. (2003). Diversity-related burnout among teachers. Teaching and Teacher Education, 19(4), 397-408. doi:10.1016/S0742-051X(03)00024-6

Theoharis, G. (2007). Social justice educational leaders and resistance: Toward a theory of social justice leadership. Educational Administration Quarterly, 43(2), 221-258.

Villegas, A. M. (2007). Dispositions in teacher education a look at social justice. Journal of Teacher Education, 58(5), 370-380.

Villegas, A. M., \& Lucas, T. (2002). Educating culturally responsive teachers: A coherent approach. New York, NY: State University of New York Press.

Whipp, J. L. (2013). Developing socially just teachers: The interaction of experiences before, during, and after teacher preparation in beginning urban teachers. Journal of Teacher Education, 64(5), 454-467. doi: 10.1177/0022487113494845. 